\title{
PENGKAJIAN ANTISIPASI AGAMA TERHADAP GLOBALISASI PEMBANGUNAN REGIONAL DAN LOKAL DI KECAMATAN BUNGORO KABUPATEN PANGKEP SULAWESI SELATAN TAHUN 1992
}

\section{A. Shadiq Kawu}

\section{PENDAHULUAN}

John Naisbitt \& Patricia Aburdene, dalam pengantar bukunya lentang Megatrend 2000, menulis bahwa kita sekarang memasuki era baru, menyongsong dasawarsa yang sangat penting dalam sejarah pcradaban manusia. Era yang ditandai gencamya inovasi teknologi, pcluang ekonomi yang tak tcrbayangkan scbelumnya, serta revormasi politik yang radikal dan bcrdampak global.

Era baru yang kita hadapi dan kita alami, sekaligus menghadapkan umat manusia pada satu dunia yang lain. Dunia yang scmakin kecil. Perkembangan teknologi, telah menjadikan hampirscgalanya menjadi sedemikian jelas. Nyaris tak ada lagi pelosok dunia yang tcrpeneil, yang berada di luar jangkauan kontrol umat manusia dengan teknologinya yang perkasa.

Relevan dengan apa yangdikemukakan Raincr Lcpsius, bahwa mcskipun, perkembangan teknologi yang demikian pesat, telah menjadikan apa yang kita alami dewasa ini, menjadi sesuatu yang lazim, lumrah dan bukan baru lagi. Tetapi, sudah pasti bahwa tingkat perkembangan teknologi mempengaruhi sekali dasar-dasar tatacara hidup dan scgala yang telah tertakdir dalam batin kita. Hal inipun bukan lagi barang baru, sckalipun harus diakui bahwa kita sckarang ini hidup disuatu zaman di rriana intensifikasi kondisi-kondisi kehidupan manusia yang dibangun secara tchnis memang tampak jauh lebih jelas. Inovasi tcknik, sepcrti halnya inovasi-inovasi yang lain, selalu menimbulkan akibat kcracunan pada tatanan-tatanan yang ada. Keadaan, situasi dan pengalaman lama yang sebelumnya telah dikenal baik liba-tiba saja berubah. Pola-pola prilaku yang semula telah dibiasakan dan telah dipercaya tampaknya tidak akan lagi bisa dianggap bcrlaku begitu saja. Dan akibat-akibat yang sekedar mengatasi kedaruratan-kedaruralan gawat yang minta disclesaikan dengan scgera. (Raincr Lepsius, 1980:17). Inovasi tcknik akibatnya tidak hanya selalu ditimbulkan inovasi teknik ilu saja, melainkan juga cara-cara bagaimana inovasi ilu dimasukan ke dalam pola prilaku yang ada.

Pcncmuan teknologi, dan pemakaiannya khususnya untuk kcpcntingan-kepcnl ingan yang bersifat pragmatik (sepcrti teknologi informasi, pertanian, listrik dan sebagainya), memang tidak selamanyadilihat dari aspek manlaatnya, akan tetapi, sejauh mana teknologi tcrsebut, telah menyebarkan efek samping yang dapat mengubah tatanan hidup masyarakat scbelumnya, yang sudah tcrlanjur dianggap mapan. Akibat dari perkembangan ini adalah munculnya gay a hidup global yang tidak dapat ditampik oleh komunitas sosial manapundi dunia ini. Pcrdagangan pcrjalanan, dan telcvisi me- 
letakkan kerangka dasar bagi gaya hidup global. Film dan media televisi menyebarkan citra yang sama ke seluruh desa global itu (John Naisbitt \& Paliricia Aburdene, 1990:20).

Dalam konteks nasional, proses pembangunan di Indonesia yang dewasa ini berada pada tahapan Pelita V, tclah melahirkan berbagai perubahan dalam masyarakat. Keberhasilan pembangunan nasional yang menganut azas terbuka dan perkembangan ilmu pengctahuan dan penemuan teknologi canggih, temtama di bidang transfortasi, komunikasi dan informasi telah membuat dunia semakin sempit. Dalam proses ini, berbagai dampak makin dirasakan pengaruhnya di tengah masyarakat, seperti. Pertama, makin meluasnya pengaruh dan unsur budaya dari luar terutama dari dunia barat, Kedua, perkembangan ekonomi dengan pola produksi industri melahirkan proses pluralisasi sosial yang makin luas dengan adanya diversifikasi industri dan jasa. Sehubungan dengan perkembangan ini, diduga muncul berbagai kecenderungan respon dari agama terhadap perubahan sosial ekonomi yang mengitarinya. Ketiga, semakin tumbuhnya saling ketergantungan dan saling tcrpengaruh antar kelompok masyarakat di dunia. Saling ketergantungan dan tcrpengaruh ini ternyata terjadi tidak seimbang. Bangsa-bangsa maju lebih berperan sebagai penekan, sedang bangsa-bangsa yang berkembang termasuk Indonesia lebih berperan sebagai pihak yang banyak tergantung dan banyak dipcngaruhi.

Tulisan ini, mencoba untuk merumuskan hasil telaah lapangan tentang bagaimana respon agama terhadap proses globalisasi. Kecenderungan respon agama terhadap penolakan sosial ekonomi dan budaya, dapat saja terjadi dalam bentuk sebagai berikut: Pertama, masyarakat mulai mempertanyakan keabsahan agama sebagai sumber legitimasi, dan sebagai akibatdari rasionalisasi dalam kalkulasi ekonomi terjadi penciutan agama. Kedua, terjadi dialog positif antara agama dengan perubahan sosial ekonomi yang mendorong ke arah reformasi dan trasformasi sosial, ekonomi, budaya scrta munculnya rumusan-rumusan baru yang merupakan legitimated values yang bersumberpada ajaran agama. Ketiga, kecenderungan munculnya reaksi balik terhadap perubahan terscbut dengan berkembangnya gcrakan ckslrim sosial seperti dalam Islam yang terlibatdari gcjala penolakan terhadap unsur yang datang dari barat. (Balitbang Agama, 1992:2).

Rumusan dari pemikiran dan kecenderun gan respon agama terhadap proses globalisasi, dijabarkan dalam pcrtanyaan-pcrtanyaan opcrasional, yang menjadi acuan makalah ini, sebagai berikut 1. Bagaimanakah agama mcmberikan antisipasi dan respon terhadap tantangan dari pengaruh trend globalisasi dewasa ini.

2. Apakah masyarakat bcragama memiliki kesiapan di dalam menghadapi trend globalisasi.

3. Apakah keragaman latar bclakang regional dan lokal berupa perbedaan geografis dan sosial budaya masyarakat Indonesia melahirkan perbedaan respon dan karakteristik pcrmasalahan keagamaan dari masing-masing dacrah.

4. Apakah berbagai kecenderungan respon agama terhadap tantangan trend globalisasi akan mempunyai dampak terhadap proses pembangunan. 
Jawaban dari pertanyaan-pertanyaan di atas, akan dikemukakan secara sederhana dalam makalah ini, yang mcrupakan hasil penclitian lapang di cmpat lokasi (dua kelurahan, dua Desa) dalam wilayah Pemerintahan Kecam atari Bungoro Kabupaten Pangkajcne Kepulauan Propinsi Sulawesi Selatan.

\section{TEMUAN DI LAPANGAN}

\section{Gambaran umum lokasi Penelitian}

Kecamatan Bungoro, adalah salah satu dari 9 Kecamatan di Kabupaten Pangkajcne Kepulauan. Letak geografisnya bcrada di persimpangan Kecam atanPangkajene (Kota Kabupaten) dengan Kecamatan Labakkang yang terletak di sebelah timurnya. Sebagian besar dari wilayah ini, membentang di sepanjang pesisir Selat Makassar. Dalam kurun waktu 20 tahun terakhir Kecamatan Bungoro, telah menjadi lokasi pembangunan obyek strategis. Salah satu diantaranya, adalah pembangunan lokasi Pabrik Semen Tonasa II, di Desa Biring Ere. Proyek ini berskalanasional, dan asset produksinya, dapat mensuply kebutuhan semen di Propinsi lain di Indonesia Bagian Timur dan di negara-ncgara ASEAN.

Pembangunan industri semen Tonasa II di Kecamatan Bungoro, telah mcmacu perkembangan desa-desa yang bcrada di jalur lintas produksi. Desa-desa yang mengalami proses transformasi yang demikian pesat, adalah desa yang terletak di daerah pusat produksi. Desa Biring Ere, yang menjadi pusat kawasan industri Tonasa, kini berkembang menjadi "kota kecil" yang dilengkapi dengan fasilitas listrik, jalan aspal, bangunan pabrik, sarana olaii raga, pendidikan, dan rasa keagamaan. Pranata tradisional, yang sebelumnya menjadi basis dalam proses integrasi sosial masyarakat, digantikan dengan lembagalembaga formal, scperti LKMD, dan organisasi remaja lainnya.

Desa Biring Ere, dalam waktu yang rclatif singkat, telah dipaksa menjadi "kota industri", semcntara masyarakatnya mengalami kesulitan dalam proses adaptasi totalnya dengan kondisi-kondisi yang serba baru. Semcntara di DesaBulu Cindea, salah satu desa yang terletak di bagian selatan kota Kecamatan, dibangun oleh Perum Semen Tonasa, menjadi "kota pelabuhan khusus" yang sekaligus menjadi pelabuhan ckspor Perusahaan.

Sebagai pelabuhan ekspor, tcrpaan globalisasi, mcmang tidak sepesat atau segencar dengan apa yang terjadi di pusat kawasan pabrik di Biring Ere, schingga masyarakat di Bulu Cindea, masih ada yang bisa mempertahankan nilai-nilai tradisionalnya, semcntara mercka berbaur dalam proses kegiatan pelabuhan. Karcna sumber daya alam yang cukup memadai untuk digarap jadi mata pencaharian penduduk, masyarakat di Desa Bulu Cindea, masyarakatnya terpola dalam mata pencaharian spcsilik, sepcrti pctani sawah, petani garam, buruh pelabuhan dan pctani tambak.

Kelurahan Sapanang, dan Kelurahan Samalcwa, adalah dua wilayah administralif sctingkat desa, yang menjadi daerah pcrantara, atau jalur lintas pemasaran produk Tonasa, dari pabrik kc pelabuhan ckspor. Oleh karcna itu, kedua kelurahan termasuk wilayah kawasan industri, schingga pembangunan jalan, yang menghubungkan antara Desa Biring Ere kc 
Desa Bulu Cindea, menjadi tanggung jawab Perum Tonasa. Kecuali sebagian wilayah Kelurahan Samalewa, yang memang berada di jalurjalan Propinsi, tidak diprogramkan Perum Tonasa.

Empat Desa, yaitu Samalewa, Sapanang, Biring Ere dan Bulu Cindea, ditetapkan sebagai lokasi penelitian, dengan pertimbangan bahwa proses globalisasi, yang terjadi di wilayah-wilayah ini, diduga jauh lebih agrcsif dibanding dengan desadesa lainnya di Kecamatan Bungoro. Dugaan ini di dasarkan bahwa kehadiran Perum Semen Tonasa, dengan teknologi beratnya telah menjadi simbol pemacu terjadinya perubahan dalam banyak aspek masyarakat. Dengan ditetapkannya sebagai lokasi penelitian, masalahnyabukan hanya, pada apakah masyarakat menerima atau menolak proses globalisasi yang terjadi di sekitarnya, tetapi juga harus mcnjawab, apakah mereka mampu atau tidak?.

Uraian tcntang kecenderungan respon agama pada masyarakat terhadap proses yang terjadi di sekitarnya, akan dikemukakan secara umum, dengan mengungkapkan bcberapa kasus yang bcrhasil diamati di lapangan.

\section{Agama dan Sosial Budaya}

Dalam kehidupan keagamaan, ada kecenderungan empat desa mengal ami, pol a yang sama, terutama proses inlernalisasi ajaran agama dalam masyarakat. Sepcrti halnya, dengan orang Bugis dan Makassar, masyarakat di lokasi ini cendcrung memeriahkan upacara keagamaan. Intcrnalisasi agama dalam bentuk pengamalan syariat secara teratur, tidak scimbang dengan antusias mereka, dalam upacaraupacara keagamaan formal, seperti pada peringatan Maulid Nabi, Isra' Mi'raj, dan scbagainya. Tradisi pembacaan barsanji masih populer, tanpa kecuali di empat desa. Masalahnya, khusus di Desa Biring Ere. masyarakatnya terpolarisasi dalam modelmodel pengamalan yang berbeda. Peringatan Maulid, misalnya,padamasyarakatyang berada di dalam kawasan industri, menyclcnggarakan Maulid di Masjid dengan mendatangkan mubaliq dari luar untuk membcrikan ceramah, sementara masyarakat di luar kawasan (kompleks) lebih cenderung mempcringali Maulid dengan upacara tradisional.

Baik di dalam kompleks. maupun di luarkompleks, masyarakat bclum mcmiliki seorang tokoh agama yang mcmpunyai kapasitas keilmuan yang cukup tinggi, dalam arti yang bisa di scjajarkan dengan "kiyai". Tetapi, sudah ada bcberapa orang yang merckakcnal dengan "uztaz". Uztaz,adalah panggilan terhadap orang-orang yang bisa membcrikan ceramah Islamiyah. Pcningkatan pemahaman ajaran agama, masyarakat di dalam kompleks, juga lebih intensif' dan terprogram. Untuk tugas sepcrti ini, mereka mcmbentuk PS IT (Persatuan Syiar Agama Islam Tonasa). Lembaga ini, bertanggungjawab untuk kegiatan keagamaan sekaligus mempersiapkan i'asilitas yang dibutuhkan. Bcda dengan masyarakat di luar kompleks. Tidak adanya tokoh agama yang secara pcrmancn berada di lengahtengah masyarakat, menyebabkan, pclayanan keagamaan tidak terkoordinasi. Apa yang ditemukan di lokasi ini, hanyalah pengajian lokal yang di bentuk atas inisiatif penduduk setempal. Untuk menjadi imam masjid masyarakat harus mendatangkan orang dari luar. Di Dusun Borong Untia, 
masjid DharmaBakti yang dibangun AMD, sampai penelitian diadakan, imam dan dojanya belum ada.

Secara umum, mubalig yang pernah datang ke Tonasa, tidak mampu membangun hubungan yang lebih intensif dengan jamaahnya. Hubungan ini bersifat temporer, sesuai jadwal kehadiran mereka. Dengan demikian, mereka tidak sampai pada pembentukan "pengikut" (dalam hubungan patron-klien). Walaupun ada sejumlah mubalig yang datang mcnawarkan gagasangagasan yang "baru" misalnya, masyarakat tetap bebas melaksanakan pesan-pesan keagamaan sesuai dengan keyakinannya.

Di Sapanang, dan Samalewa, kehidupan keagamaan mengalami intervensi dari gaya hidup global. Pada beberapa kasus, agama walaupun mengalami terpaan yang cukup keras dari perubahanperubahan yang terjadi di sekitarnya, masih tetap menjadi sumber motivasi.

Kasus alihteknologipcmbajakansawah dari kerbau ke Traktor misalnya, sejak pertama kali di pcrkenalkan sekitar 1980an, tidak serta merta diterima olch pctani lokal. Ada perasan ragu, apakah penggantian teknologi itu, secara otomatis dapat meningkatkan produktivitas petani, atau malah scbaliknya. Sama dengan apa yang dikemukakan James S Scoot (1976:53) bahwa sikap petani seperti ini, disebabkan karcna mereka lebih suka melaksanakan teknologi lama, yangmeskipundiperkirakan tidak sebesar produktivitasnya dengan pemakaian teknologi baru; tetapi pola lama telah terbukti bagi petani, sementara teknologi baru belum menjamin, kemungkinan mencapai target produksi maksimal.

Pada tahun 1988, pemakaian traktor sudah mulai dikenal pada sebagian petani pemilik di Sapanang. Kecuali hanya satu Kelompencapir, yang sampai tahun 1992 masih menolak pemakaian traktor, dan anggotanya tetap menggunakan kerbau, dengan cara kerja secara kolektif dan bergotong-royong.

Diterimanya teknologi baru dalam pembajakan sawah, ternyata tidak hanya karena petani sudah melihat manfaatnya. Akan tetapi, karcna pemakaian teknologi baru, semakin mcmberi peluang para petani untuk beribadah. Scorang informan mengemukakan, bagaimana penggantian teknologi itu, mengubah pola ritual pctani. Misalnya saja, dengan menyewa traktor, petani tidak pcrlu lagi ke sawah. Karena kontrak sewa kerja dengan pemilik traktor, telah mengurangi beban petani di kebun atau sawah. Padahal sebclumnya, seorang pctani, sudah ada di sawah sebelum waktu subuh tiba. Hal ini dilakukan, karena mereka tidak dapat bckcrja pada saat matahari sudah tinggi. Dengan adanya traktor, petani sudah bisa melaksanakan sholat subuh di masjid atau di rumah, tanpa dibayangi kegiatan di sawah.

Di Bulu Cindea, karcna mata pencaharian penduduk bervariasi, maka pola kehidupan keagamaan juga lerpola pada lingkup pekerjaan. Misalnya petani garam, petani sawah dan pctani sawah tambak. Pada umumnya, waktu berkunjung ke masjid adalah pada hari Jumat. Scdang pclaksanaanjamaah magrib, isya dan subuh tidak seramai dengan hari Jumat. Karena tingkal pendidikan relatif rendah. anggota masyarakat lebih cenderung bersikap pragmatik. Kerja adalah cita-cita orang tua terhadap setiap anaknya, dan bukannya 
sekolah. Ada pendapat bahwa melanjutkan pcndidikan bagi anak (setelah tamat SD) adalah mubazir dan tidak menjamin masa dcpan. Kenyataan ini didukung, bebcrapa orang yang sudah tamat SMA, lapi tidak scmpat bekerja di kantor milik pemerintah.

Ada kasus lain yang ditcmukan di Bulu Cindea. Berbeda kasus petani Sapanang, yang mulanya cnggan menerima teknologi bam, kemudian menerima setelah yakin akan manfaat yang diberikan teknologi itu. Di Bulu Cindea, petani garam, terlebih dahulu menerima teknologi pembuatan garam yang diperkenalkan penyuluh pertanian. Tetapi, dalam proses pemakaiannya, petani melihat kualitas produksi dengan teknologi baru lebih rendah dibanding dengan teknologi tradisional. Oleh karena itu, petani garam kemudian menolak pemakaian teknologi baru yang terbuat dari besi. Penolakan ini, karena petani menilai, "sifat besi berbeda dengan sifat garam". Besi berkarat, sedang garam tidak. Pertentangan ini, kemudian terlihat, dengan berubahnya warna garam dari warna putih jernih menjadi ke coklat-coklatan. Perubahan warna, adalah perubahan kualitas garam, dan hal ini juga mempengaruhi harga produksi.

Fenomena tersebut di atas, menegaskan bahwa inovasi tehnik yang ingin diterima masyarakat memang harus memperoleh dasar pembenar yang kokoh; dan pembenaran atas inovasi ini selalu cenderung menekankan pada segi-segi keuntungan-keuntungan yang dipcrlihatkan olehnya, dan tidak banyak memperhitungkan kemungkinan kerugian yang bisa timbul (Rainer Lepsius, 1980:20).

\section{Respon Agama Terhadap Globalisasi}

Globalisasi, telah menghembuskan nilai-nilai baru dalam kehidupan masyarakat desa di Kabupaten Pangkep. Hasrat dan keinginan untuk berkenalan dengan nilai-nilai barujuga semakin nam pak dalam masyarakat. Hasrat seperti ini, terjadi di kalangan anggota dan elit masyarakat desa. Hal ini dapat dibuktikan dengan aktifnya, mercka menonton acara-acara TV, terutama pada acara-acara hiburan (lagu dan film) di Biring Ere Siaran pedesaan di Sapanang, dan dunia dalam berita, serta berila lainnya di Samalewa dan Bulu Cindea.

Di Biring Ere, acara hiburan, nampaknya masih terbatas pada keinginan yang bcrsifat temporer, atau hasrat untuk beristirahat. Hal ini, dapat diamati, dengan pengakuan sejumlah informan yang tidak tertarik untuk meniru prilaku aktor atau aktris film, drama dan sinetron dalam pola kehidupan mercka sehari-hari. Oleh karena itu, meskipun anggota masyarakat gemar mcnonton, itu berarti bahwa media televisi hanyadijadikanmediahiburansemata-mata.

Misalnya, kalau ada acara televisi yang mercka tidak sukai, mercka seringkali melontarkankalimatyang bersifatmcnolak atau mengejek.

Gencarnya, informasi yang diperoleh dari televisi dan radio, menyebabkan ada beberapa siaran media elektronik itu, yang mendorong masyarakat melakukan tindak lanjut dalam bentuk kegiatan kemasyarakatan, yang relevan dengan materi siaran yang mercka ikuti di televisi. Kasus Biring Ere, di mana Mimbar Agama Islam yang ditayangkandi televisi setiapmalam Jumat, 
mendorong, pengurus PSIT (Persatuan Syiar Islam Tonasa) membantu anggota masyarakat di luar kompleks untuk mendatangkan mubaligdari luar dan memberikan ceramah keagamaan ditengah-tcngah mereka. Dorongan ini didasarkan bahwa siaran agama di telcvisi, di dorong agar mereka dapat me-nerima ceramah agama lewat para mubalig yang berkunjung ke desa Biring Ere.

Di Sapanang, dan Samalewa, masyarakat menilai acara mimbar agama Islam melalui radio dan televisi, sangat bermanfaat dalam proses internalisasi ajaran agama. Seorang informan di Sapanang, menuturkan, bagaimana cfektifnya siaran agama Islam di televisi dan radio. "Dulu, kalau kita mau mcnambah pengetahuan agama, kita harus ke Parepare, atau kc Ujungpandang dan berguru pada Kiyai, tetapi sckarang, kita tinggal di rumah dan dapat mengatur jadwal siaran agama lewat radio dan televisi,". Informan ini, tidak saja mengikuti siaran agama di Televisi dan RRI, tapi juga di radio-radio swasta yang memang sering menyiarkan acara keagamaan, baik yang menggunakan bahasa Indonesia, maupun bahasa daerah (Bugis, Makassar).

Bagaimana respon agama terhadapjasa perbankan, dan keluarga berencana. Masalah ini juga sangat bervariasi. Di Bulu Cindea, masyarakat terpola dalam bentuk model penerimaan atau penolakan lerjadap jasa bank. Untuk pemuka masyarakat, atau yang termasuk kelompok elit desa, pada umumnya mereka telah menerima baik jasa bank dalam kegiatan sehari-hari. Mereka tidak lagi mcmpermasalahkan apakah masalah itu, sudah mendapat kescpakatan para ulama atau belum. Yang jelas, mereka melihat manfaat menyimpan uang di bank jauh lebih aman dari pada menyimpan atau meminjam pada tetangga. Hubungan simpan pinjam uang dengan tetangga, seringkali mendatangkan konflik yang menjurus pada putusnya silaturrahmi.

Di Bulu Cindea, ada sckitar 200 orang yang menyimpan uang di BRI Unit Desa. Jenis simpanan juga bervariasi, seperti, Simpcdcs, Simaskot, Tabanas dan Deposito. Jumlah uang yang tcrsimpan di BRI Unit Desa Bulu Cindea, bcrkisar Rp.300.000.000,00. Selain yang menyimpan, ada pula yang mengambil kredit. Pcngambilan kredit untuk modal kerja di Bulu Cindea, ada sepuluh orang dengan nilai kredit 100 jula rupiah.

Yang monarik, karena pengambilan kredit bank, tidak saja sekedar untuk modal kerja, di sektor pertanian. industri dan sebagainya. Ada pula kredit yang digunakan untuk pembangunanmasjid dan saranajalan.

Upaya untuk memasyarakatkan manfaat bank bagi masyarakat, dilakukan dengan mengadakan penyuluhan. Penyuluhan ini disponsori pcmerinlah desa bekcrja sama dengan tokoh agama. Intensifnya, penyuluhan di Bulu Cindea, menyebabkan frekwensi hubungan dengan bank jauh lebih tinggi dibandingkan dengan Desa atau Kelurahan Sapanang. Di Sapanang, masih ada penduduk kelurahan yang enggan mencrima jasa bank, baik dalam bentuk pengambilan kredit Usaha Tani maupun menyimpan uang dalam bentuk Simpcdes. Meskipun, pemerintah Kelurahan sudah mengadakan penyuluhan, tetapi masih banyak anggota masyarakat yang enggan mclakukannya.

Ada sejumlah informan di Sapanang, yang lebih suka menyimpan uang di dalam 
bentuk pembelian emas, dari pada menyetor ke bank. Alasan mcreka sangat sederhana, yaitu mereka ragu apakah dengan berhubungan bank, seseorang tidak menyimpang dari prinsip agama yang dianutnya. Penolakan ini juga bertolak dari anggapan bahwa mengambil dan atau mcnyimpan uang di bank hukumnya riba, atau haram.

Bagi masyarakat yang sudah menerima bank, juga mendasarkan penerimaannya pada ajaran agama. Informan lain di Biring Ere mengemukakan, bahwa sudah ada ulama yang memfatwakan mengambil dan menyimpan uang di bank pemcrintah hukumnya halal (bolch saja), karena bank itu misinya adalah untuk kepentingan umum. Alasan sepcrti ini yang dipegang tokoh-tokoh masyarakat di semua desa sampcl. Dalam mengemukakan alasan terse but, tak ada informan yang mengemukakan alasan sikapnya (menerima atau menolak), hanya dengan alasan manfaat saja, tetapi selalu berdasarkan pertimbangan bolch dan tidak bolch menurut fatwa ulama yang mereka ketahui.

Pada dasarnya, ada dua alasan pokok yang selalu mereka kemukakan, sctiap kali monghadapi hal-hal baru dalam masyarakat. Pcrtama, alasan keagamaan (bolch dan tidak bolch menurut hukum agama), dan kedua, alasan manfaat, atau kegunaannya hal tersebut bagi keluarga (baik secara individual maupun dengan komunitas sosial). Sikap sepcrti ini pula yang ditunjukan kctika mereka bcrhadapan dengan program Keluarga Berencana Pemakaian kondom, spiral (IUD) sampai sckarang, belum ada yang menggunakannya. Peserta KB di desa-desa sampcl, pada umumnya mcnggunakan suntikan. Penolakan secara tcgas mereka buktikan terhadap instrumen KB lainnya, sepcrti Castrasi (kebiri), Vasectomi, untuk pria. Khusus wanita, sepcrti opcrasi kaisar (pemotongan kandungan) atau Cigasi (pengikatan salurankesuburan), scmuanya masih ditolak dengan alasan hal tcrscbul bcrtentangan dengan fitrat kemanusiaan, dan tidak dircstui agama. Penolakan ini didukung anggapan bahwa, program KB yang bcrmaksud membatasi kelahiran bcrtcntangan dengan kehendak agama yang mcnetapkan bahwa anak adalah bcrkah bagi keluarganya. Dan setiap orang diciptakan masing-masing dengan rezckinya sendiri-sendiri.

Ada dua instrumen teknologi baru yang langsungditcrima masyarakat tanpamclalui proses "penolakan" atau "coba-coba" yaitu, pemakaian lislrik untuk kcpcrluan rumah langga, dan penggunaan pupuk buatan menggantikan pupuk kandang untuk menyuburkan tanah pcrtanian.

Empat desa yang diamati, yaitu Biring Ere, Sapanang, Samalcwa dan Bulu Cindca. menerima instrumen tersebut lebih ccpat dibanding dengan "sikap ragu-ragu" yang mereka perlihatkan dalam menerima Bank. KB dan scbagainya. Di Sapanang maupun di Biring Ere, listrik telah menjadi kebutuhan hidup masyarakat yang tak dapat lagi abaikan. Masuknya listrik ke rumahrumah penduduk, sekaligus mcmpcrkenalkan kepada mcreka instrumen teknologi lainnya yang sangat vital, seperti televisi. Listrik juga, semakin menggairahkan penduduk untuk bcrkunjung ke masjid, mengikuti sholat jamaah. Berkat listrik ini pula, di masjid-masjid dusun, dapat dilengkapi dengan alat pengeras suara. Waktu-waktu 
mcnjelang magrib, isya dan subuh misalnya, masyarakat akan cepat diingatkan datangnya waktu sholat, karena lewat alat pengeras suara, pengurus masjid memutar rekamanpengajian ayat-ayatsuci Al Quran. Kehadiran listrik melalui PLN di Bulu Cindea, telah merupakan rahmat tersendiri bagi masyarakat. Kalau sebelumnya, mereka menggunakan aki untuk dapat menonton siaran tclevisi, dengan adanya listrik, biaya dengan menggunakan aki, jauh lebih besar dibanding dengan tenaga listrik. Apalagi, lenaga listrik bukan hanya sekedar untuk menonton tclevisi, melainkan juga untuk kebutuhan rumah tangga lainnya, seperti, lemari es (kulkas), mcsin cuci dan sebagainya.

Diantara sekian instrumen teknologi baru yang masuk ke desa sampel. Tclevisi, merupakan media yang paling akrab dengan warga desa. Dengan adanya TPI (Tclevisi Pcndidikan Indonesia) yangjadwal siarannya di siang hari, masyarakat dan ibu-ibu rumah tangga, dapat menikmati siaran tclevisi, siang maupun malam. Ada dua sikap masyarakat yang menonjol, tcrutama untuk mempcrlihatkan rasa tidak suka dengan suatu siaran atau acara di tclevisi. Pertama, dengan cara "menccrca" acara tcrsebut. Anak-anak muda, atau orang lua yang mclihat ada acara di tclevisi, di mana pelaku acaranya mengenakan pakaian yang oleh mereka dianggap tidak sopan, maka penonton langsung tertawa screntak. Bagi orang-orang tua ada yang scring meninggalkan acara itu. Siaran Mimbar Agama non Islam misalnya, oleh para orang tua di desadesa, melarang anak-anaknya, untuk mengikuti acara itu. Biasanya, televisi itu ditinggalkan dengan mcmbiarkannya jalan tanpa penonton. atau dengan cara memati- kan atau menghentikan acara itu.

Satu hal yang sangat terasa bagi masyarakat, terutama yang berusia di atas lima puluh tahun, adalah kekuatiran mereka terhadap menipisnya emosi keagamaan para remaja desa. Kehidupan keagamaan, mereka nilai, cenderung sangat formalistik tanpa diimbangi penghayatan yang sarat emosi. Seorang informan di Salebbo Kclurahan Sapanang menccritakan, bagaimana doadoa yang dipanjatkan kepada Tuhan tidak lagi seperti tahun-tahun tiga puluhan. Dulu, dengan mcmbaca Al Fatiha saja scseorang bisa mengobali penyakit-penyakit yang dialami penduduk, tetapi sekarang, biar membaca separoh ayat dalam Al Quran, tampaknya tidak akan semanjur dulu.

Menipisnya emosi keagamaan, merenggangkan kcierikatan remaja kepada nilai-nilai agama dan adat. Anak muda semakin lepas kontrol, rasa hormat kepada orang tua merosot dan sebagainya.

\section{PENUTUP}

Kcsimpulan

1. Proses globalisasi pembangunan yang berlangsung secara cfektif di Kccamatan Bungoro, telah mengubah wajah desa secara total. Wajah desa tradisional dengan penduduk yang terkonsentrasi pada pcrtanian subsislensi, berkembang menjadi kotakccil. Homogenitas budaya, dan ketergantungan pada nilai-nilai tradisional, bergeserkepadapolahidup baru, dengan kompetisi individual yang kclat. Masyarakat terpoladalam subkulturbaru yang dihasilkan oleh pembangunan.

2. Nilai-nilai budaya lama yang bcrdasarkan gotong royong, mulai terkikis sc- 
mangatindividualisme. Pranata si tuning tulung (kerjasama tradisional) yang pernah menjadi simbol keakraban petani lokal, semakin lama semakin pudar. Konsep situlung-tulung sekarang, hanya simbol solidaritas petani kecil yang kekurangan modal kerja, dan tingkat produksi yang rendah.

3. Globalisasi, menjadikan masyarakat semakin kritis. Penggunaan instrumen teknologi secarabertahap (inform asi.pcrtani an, j asa, perd agangan d an scbag ain y a) telah merenggangkan keterikatan penduduk pada kepcrcayaan tradisional, yang menganggap alam penuh misteri dan harus dihadapi dengan kekuatan magik.

4. Respon terhadap globalisasi sangat bervariasi, sikap menolak dan menerima trend globalisasi, tergantung pada sejauh mana hal tersebut memberikan manfaat dalam kehidupan masyarakat, dan sejauh mana mercka melihatnya relevan dengan agama yang dipeluknya.

\section{DAFTAR KEPUSTAKAAN}

Naisbitt \& Aburdene, Megatrend 2000, Warta Ekonomi, Jakarta 1990

Rainer Lcpsius dalam Soetandyo, Perubahan Sosial, Universitas Airlangga, Surabaya 1976
Mukhlis Ed, Dimensi Sosial Kawasan Pantai,P3MP, Unhas, UjungPandang 1987

Agama dan Rcalitas Sosial, Universitas Hasanuddin, Ujung Pandang 1985

Alpian, Transformasi sosial budaya, UI Press, Jakarta 1986. 